\title{
A comparison of the larvivorous habits of exotic Poecilia reticulata and native Aplocheilus parvus
}

\author{
G. K. Achini W. Fernando', Sevvandi Jayakody ${ }^{*}$, W. M. Hiranya K. Wijenayake1', Gawrie N. L. Galappaththy², \\ Mangala Yatawara ${ }^{3}$ and Jeevanie Harishchandra ${ }^{4}$
}

\begin{abstract}
Background: The exotic fish Poecilia reticulata is promoted in the tropics as a biological control agent for aquatic pathogenic carriers, such as mosquitoes. Such control measures are often adopted blindly, ignoring the potential of native species and the adverse effects of introduced species. The present study was conducted to assess the diet composition of two species of fish, the native Aplocheilus parvus and exotic P. reticulata, and to assess the availability of food items in their natural environment in four types of aquatic systems. Diet composition was estimated using $24 \mathrm{~h}$ gut contents analysis, in a clay quarry pit and a perennial reservoir for A. parvus, and in a man-made canal and a second-order natural stream for $P$. reticulata. Food items in these environments were quantified by analyzing water samples collected every $2 \mathrm{~h}$.
\end{abstract}

Results: The diet of A. parvus in the clay quarry pit and reservoir consisted of adult or larval stages of Insecta, Maxillopoda and Malacostraca. In both habitats, A. parvus selectively fed on insect parts and insect larvae. The diet of P. reticulata consisted of filamentous algae, diatoms and detritus. The diet of $A$. parvus showed active selection of insectivore food items against their low availability. In contrast, the diet of $P$. reticulata showed consumption of food items in accordance with their availability in the environment. The highest mean number of food items in the gut for A. parvus was recorded around mid-day in the clay quarry pit, but no peak feeding time was identified in the perennial reservoir. For $P$. reticulata, peak feeding was recorded around mid-day in both the habitats.

Conclusion: Irrespective of the type of environment and rate of occurrence, A. parvus preferred insect and insect larvae, whereas $P$. reticulata consumed the most readily available food items. The active selection of insects by $A$. parvus suggests they may have value as a biological control agent.

Keywords: Aquatic ecosystem, Biological control, Diet composition, Fish

\section{Background}

Fish are being introduced to new areas as biological control agents [1] for insect-related vector-borne diseases [2, 3]. However, this practice is sometimes questioned due to damage to non-target organisms and ecosystem functioning $[4,5]$ and the invasiveness of exotics [6]. The species Poecilia reticulata is a known invasive [7, 8], but has

\footnotetext{
*Correspondence: sevvandi_jayakody@yahoo.com

${ }^{1}$ Department of Aquaculture and Fisheries, Wayamba University of Sri Lanka, Makandura, Gonawila, Sri Lanka

Full list of author information is available at the end of the article
}

been introduced to many parts of the world as a biological control agent $[9,10]$.

In many instances, the potential of native fish species for biological control has not being explored, although the practice is encouraged [11] and promising results have been obtained from a handful of studies [12-14]. Since the family Aplocheilidae are already recognized as predators and have been proven to control the larval stages of aquatic insects $[15,16]$, the diet composition of the native Aplocheilus parvus was compared with the exotic $P$. reticulata in some selected water bodies in Sri Lanka. $P$. reticulata has spread along rivers and other 
waterways to new locations [17] and can now be found in both lotic and lentic environments. Aplocheilus parvus is a surface dwelling fish species inhabiting lotic and lentic systems in wet, intermediate and dry zones of Sri Lanka, both in moderately saline and fresh waters, where $P$. reticulata has been introduced as biological control. However, the diet of $P$. reticulata, in relation to available food sources, has not been evaluated in these new habitats. The objective of the current study was, therefore, to evaluate the food choices of $P$. reticulata and $A$. parvus in the aquatic systems where they live.

\section{Methods}

Diet composition for both species was determined by 24-h gut contents analysis [18]. Initially their presence in the different aquatic systems was assessed, in order to select appropriate sampling locations. Accordingly, diurnal and nocturnal surveys were carried out in an abandoned clay quarry pit $\left(7^{\circ} .3280^{\prime} \mathrm{N} ; 80^{\circ} .0241^{\prime}, \mathrm{E}\right)$ and in a perennial reservoir $\left(7^{\circ} .1733 \mathrm{~N} ; 79^{\circ} .9619 \mathrm{E}\right)$ for $A$. parvus. A man-made canal $\left(7.1314^{\circ} \mathrm{N} ; 79.8764^{\circ} \mathrm{E}\right)$ and a secondorder natural stream $\left(7.2268^{\circ} \mathrm{N} ; 80.1958^{\circ} \mathrm{E}\right)$ were surveyed for $P$. reticulata, as they represent the main aquatic systems to which this species has been introduced. Sampling was carried out between 2012 and 2013 (A. parvus: January 2012 and May 2013, P. reticulata: April 2012 and June 2013). Prevailing weather prevented starting of sampling at the same time.

At each of 4 different sampling sites, samples of 12 fish consisting of both males and females of $A$. parvus (weight: $\bar{x}=0.14 \pm 0.004 \mathrm{~g} \mathrm{SD}$; total length: $\bar{x}=25.5 \pm 2.89 \mathrm{~mm}$ SD) and $P$. reticulata (weight: $\bar{x}=0.2078 \pm 0.1258 \mathrm{~g} \mathrm{SD}$; total length: $\bar{x}=25.050 \pm 4.334 \mathrm{~mm} \mathrm{SD}$ ) were collected at 2-h intervals for $24 \mathrm{~h}$, resulting in a total of 144 fish per site. The fish were immediately transferred to a freshly prepared solution of $10 \%$ buffered formalin. A plankton net $(110 \mu \mathrm{m}$ mesh size and $26.4 \mathrm{~cm}$ in diameter) was dragged for $5 \mathrm{~m}$ at the water surface to collect natural food items and the contents were preserved in 5\% buffered formalin and Lugol's Iodine solution, for zooplankton and phytoplankton respectively, at every sampling $[19,20]$. Later, all the specimens were blotted and weighed. Standard length and total length were measured and the fish were carefully dissected and their guts removed. For each fish, the length and weight of the gut were obtained. Gut fill (the fraction filled out of 10 parts) was recorded for each fish and the types of material in the gut were recorded using a Sedgewick Rafter Cell. A common copepod was taken as the arbitrary unit for $A$. parvus. Several copepods were selected and their length and width were recorded to calculate the area. After determining the mean area of a copepod, every food item identified were measured for length and width. The total area of a given food item was divided by the mean area of a copepod to determine the number [21,22]. In P. reticulata, only the anterior part of the gut (the stomach and a small part of the foregut at the point where the gut turns $180^{\circ}$ ) was used in the analyses and a common diatom was used as the arbitrary unit. A total of 576 gut samples were analyzed with 144 samples per species per site.

Food particles in the water samples were analyzed separately for all four sites at each time period, with dilution where necessary, using 100 cells of a Sedgewick Rafter Cell. A common diatom was taken as the arbitrary unit.

Tukey's mean separation was used to identify differences in gut fill. Interactions between sex, time The mean numbers of different types of food particles present in the gut, for each species, at each sampling time and at all four sites were calculated and then used to identify the times of peak gut fill for each sex of each species at each site. Analysis of variance (ANOVA) with, site and species, on the mean number of each food item present, were estimated by one-way and two-way ANOVA. Where the data were unbalanced, General Linear Models were used. The number of different types of food particles present in the gut and in the environment were converted into percentages of occurrence and the data were used to help understand the relationships between consumption and availability. Further, Electivity Index of Ivlev (1961) was calculated to find out the selectivity of food items against the availability in the environment.

\section{Ethical committee}

Approval for collection and sacrifice of fish and other field work was obtained from the Faculty of Graduate Studies of University of Kelaniya, Sri Lanka and the Ethics Committee of the Wayamba University of Sri Lanka, in the Faculty of Livestock, Fisheries and Nutrition. Collection of $A$. parvus from the wild was done with the permission from Department of Wildlife Conservation, Sri Lanka.

\section{Results \\ Diet of $A$. parvus}

Food items detected in the clay quarry pit and reservoir environments consisted of filamentous algae, detritus, copepods, insect parts and other items, which included plant parts, eggs and other unidentified materials. While copepods and filamentous algae were the main food items in the clay quarry pit, detritus represented the highest percentage of food items in the reservoir.

The diet of A. parvus in the clay quarry pit and the reservoir consisted of adult or larval stages of the classes Insecta, Maxillopoda and Malacostraca. Both adult and larval stages of Coleopterans were detected in the gut of $A$. parvus in both environments, whilst Hymenopterans 
were detected only in the gut of $A$. parvus inhabiting the clay quarry pit. Additionally, food items such as plant parts, eggs and other unidentified materials were present in the gut at both the sites.

Whilst Coleoptera were the main food item (40\% of gut fill) of $A$. parvus in the clay quarry pit, unidentified insect parts were the main food item $(63 \%)$ in the reservoir (Fig. 1a, b).

The highest mean number of food items in the gut was detected at mid-day, around $1230 \mathrm{~h}$, in the clay quarry pit (Fig. 2a) and the mean number of food items during that time was significantly higher than all other times (ANOVA, $d f_{11,120}, \mathrm{P}<0.005$ ). By contrast, in the reservoir, $A$. parvus did not show a peak feeding time (Fig. $2 \mathrm{~b}$ ).

Gut fill results indicated that $A$. parvus is a diurnal feeder, as gut fill values were higher in daytime, but there was no difference in gut fill between the sexes and the diurnal patterns of feeding for both sexes in the two habitats were similar (Fig. 3).

For A. parvus in the clay quarry pit, total insect parts (unidentified insect parts, insect larvae, Hymenopterans and Coleopterans) ranged from $67.77 \%$ at $0830 \mathrm{~h}$ to

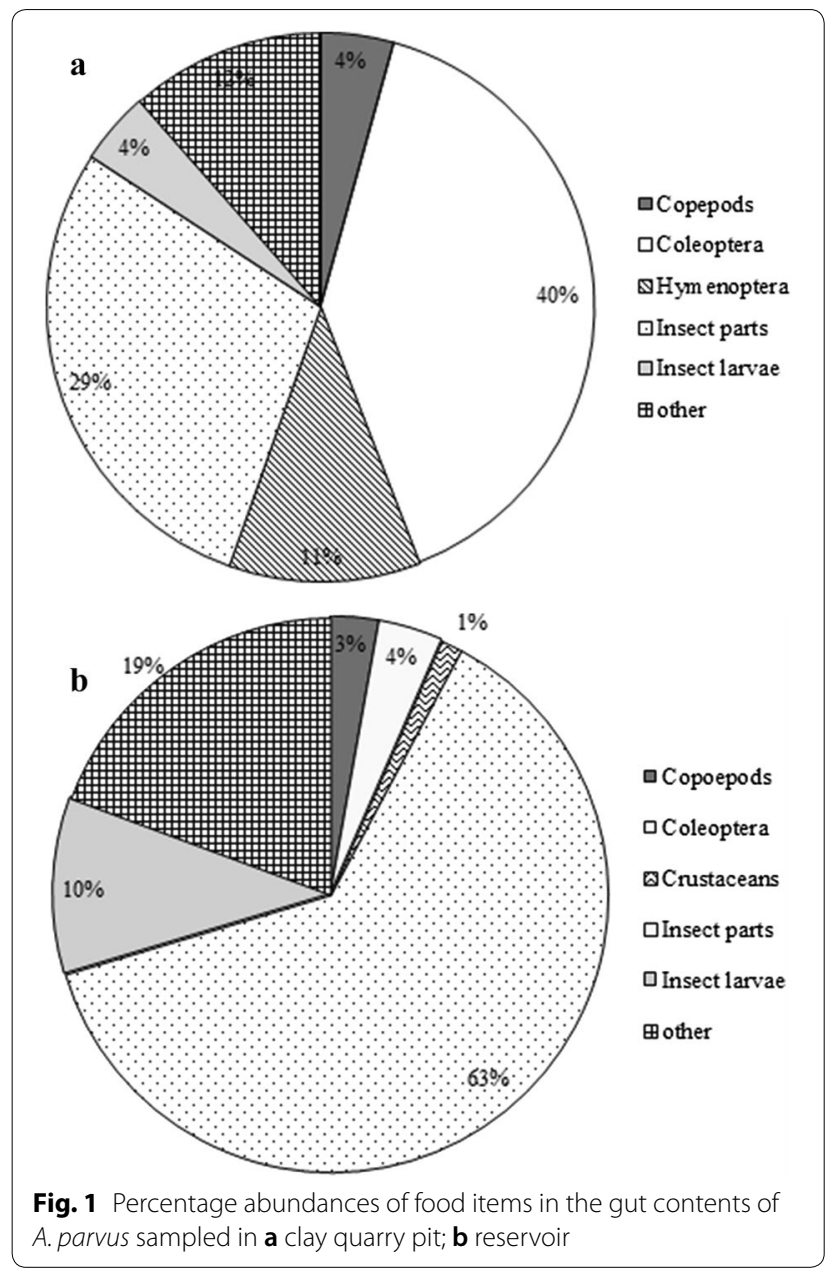

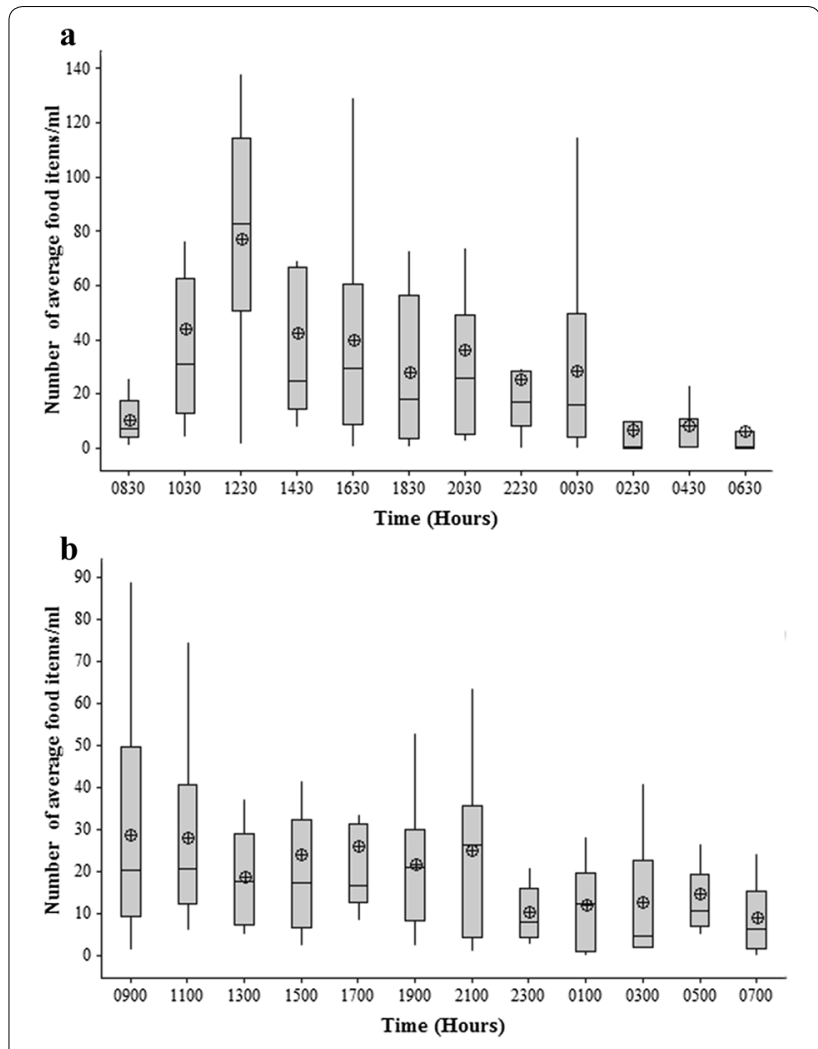

Fig. 2 Fluctuations in number of mean food items with time in the gut contents of $A$. parvus sampled in $\mathbf{a}$ clay quarry pit and $\mathbf{b}$ reservoir. The box plot whiskers depict the range and circled crosses depict the mean number of food items at each time

98.53\% at $1230 \mathrm{~h} \mathrm{(Fig.} \mathrm{4a).} \mathrm{In} \mathrm{the} \mathrm{reservoir,} \mathrm{total} \mathrm{insect}$ parts (unidentified insect parts, insect larvae and Coleopterans) ranged from $50.94 \%$ at $0900 \mathrm{~h}$ to $99.53 \%$ at $1300 \mathrm{~h}$ (Fig. 4b).

\section{Diet of $P$. reticulata}

Food items detected in the man-made canal and natural stream environments consisted of filamentous algae, detritus, copepods, insect parts and other items, which included plant parts, eggs and other unidentified materials. While copepods and filamentous algae were the main food items in the man-made canal, detritus represented the highest percentage of food items in the natural stream.

The diet of $P$. reticulata in the man-made canal and natural stream environments consisted of filamentous algae, diatoms, detritus and other food items, which included plant parts, eggs and unidentified parts. In addition to those food items, approximately $5 \%$ of insect parts were also detected in fish collected from the natural stream (Fig. 5a). Whilst filamentous algae and detritus were the main food items in the gut in the man-made canal, 


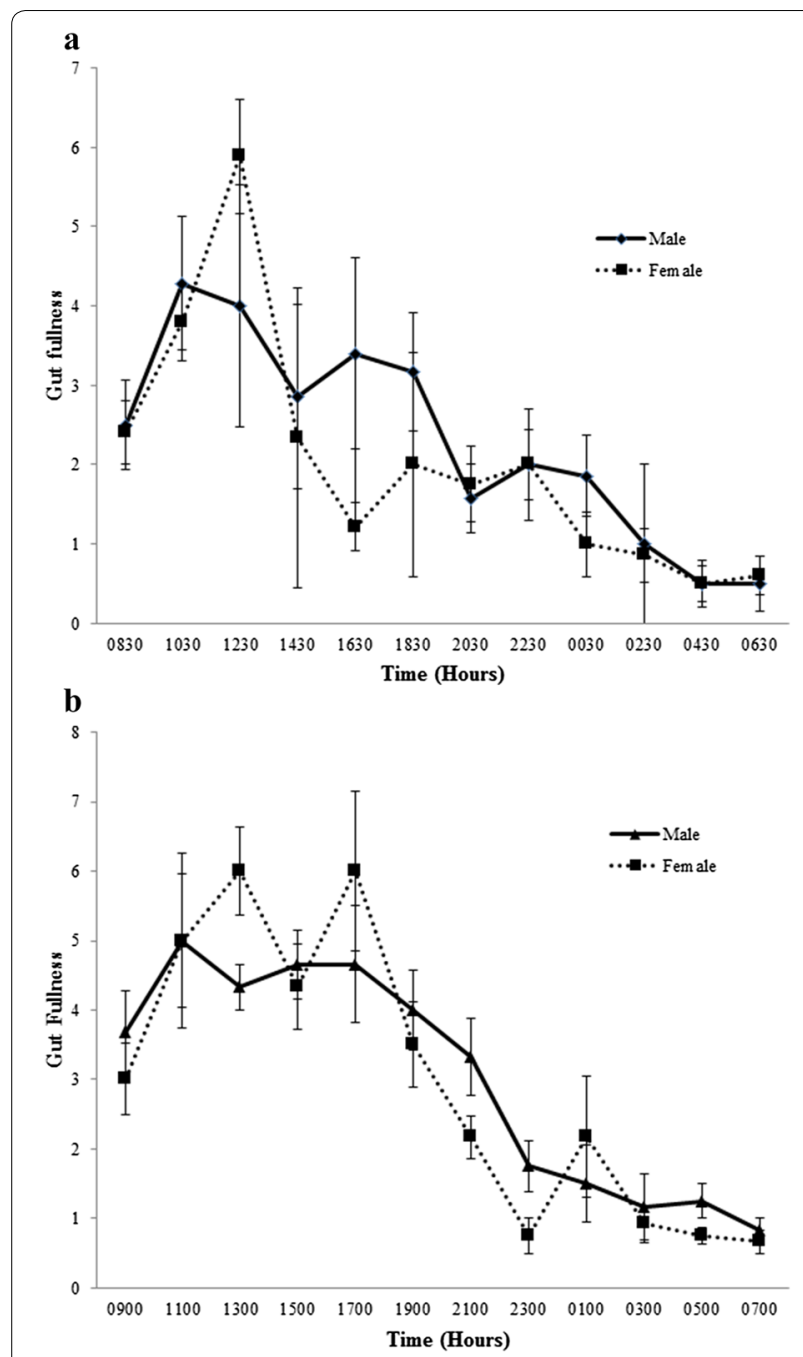

Fig. 3 Fluctuations in gut fill ( \pm SE) of A. parvus with time for females (depicted with square and hatched lines) and males (depicted with triangle and solid line) in $\mathbf{a}$ clay quarry pit and $\mathbf{b}$ reservoir

detritus and other types of food items were the main items consumed in the natural stream (Fig. 5b).

Poecilia reticulata had a higher mean number of food items in the gut in daytime compared to during the night and at dawn, in the man-made canal (ANOVA, $d f$ $\left.{ }_{11,128}, \mathrm{P}<0.005\right)$ (Fig. 6a). An almost identical pattern was seen in the natural stream (ANOVA, $d f_{11,131}, \mathrm{P}<0.005$ ) (Fig. 6b). Diatoms, filamentous algae and detritus accounted for over $90 \%$ of the diet (Fig. 7a).

In the natural stream, detritus was detected in the gut throughout the sampling period and ranged from $31 \%$ of gut fill at midnight to $92.29 \%$ at $1000 \mathrm{~h}$. Detritus ranged

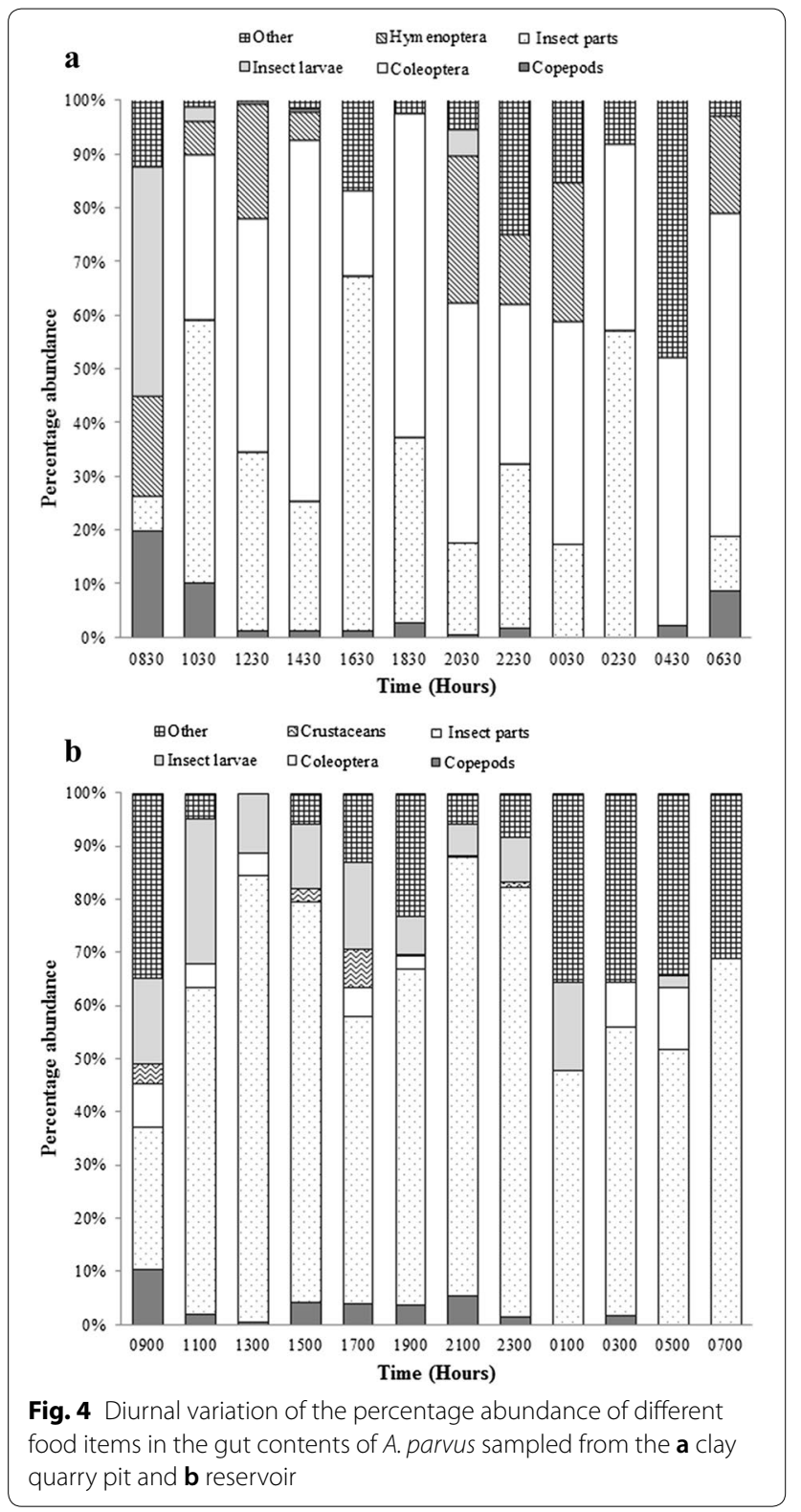

between $22.65 \%$ of gut fill at $2200 \mathrm{~h}$ to $92.29 \%$ at $1000 \mathrm{~h}$. Insect parts were present only in P. reticulata in the natural stream (Fig. 7b).

\section{Comparison between availability of food items and diet composition}

In the clay quarry pit $A$. parvus fed selectively on zooplankton and insect parts, with greater amounts 


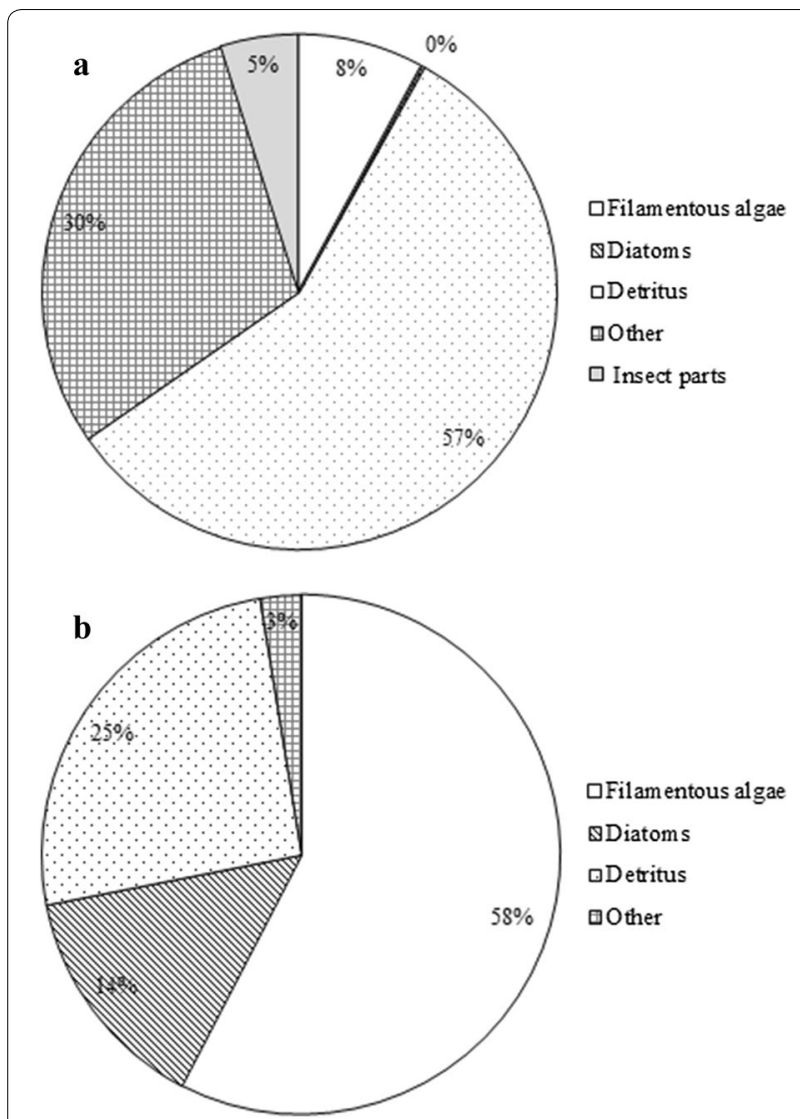

Fig. 5 Percentage abundance of food items in the gut contents of $P$. reticulata collected from $\mathbf{a}$ natural stream and $\mathbf{b}$ man-made canal

consumed than were available in the environment (Fig. 8a) and avoided phytoplankton despite their greater availability (Fig. 8b). The same phenomenon was seen in the reservoir (Fig. 9a, b).

The gut contents of $P$. reticulata comprised a significantly higher percentage of phytoplankton in both habitats (Figs. 10b and 11b). While the percentage of zooplankton and insect parts in the gut was almost zero, the percentage in the environment was comparatively higher (Figs. 10a and 11a) in the man-made canal $(17.03 \% \pm 10.51)$ and in the natural stream $(2.7 \% \pm 5.24)$.

Results of Electivity Index of Ivlev (1961) (Table 1) further confirmed that $A$. parvus had a higher selection over zooplanktons and insect parts in both the sites, while $P$. reticulata elected for phytoplankton.
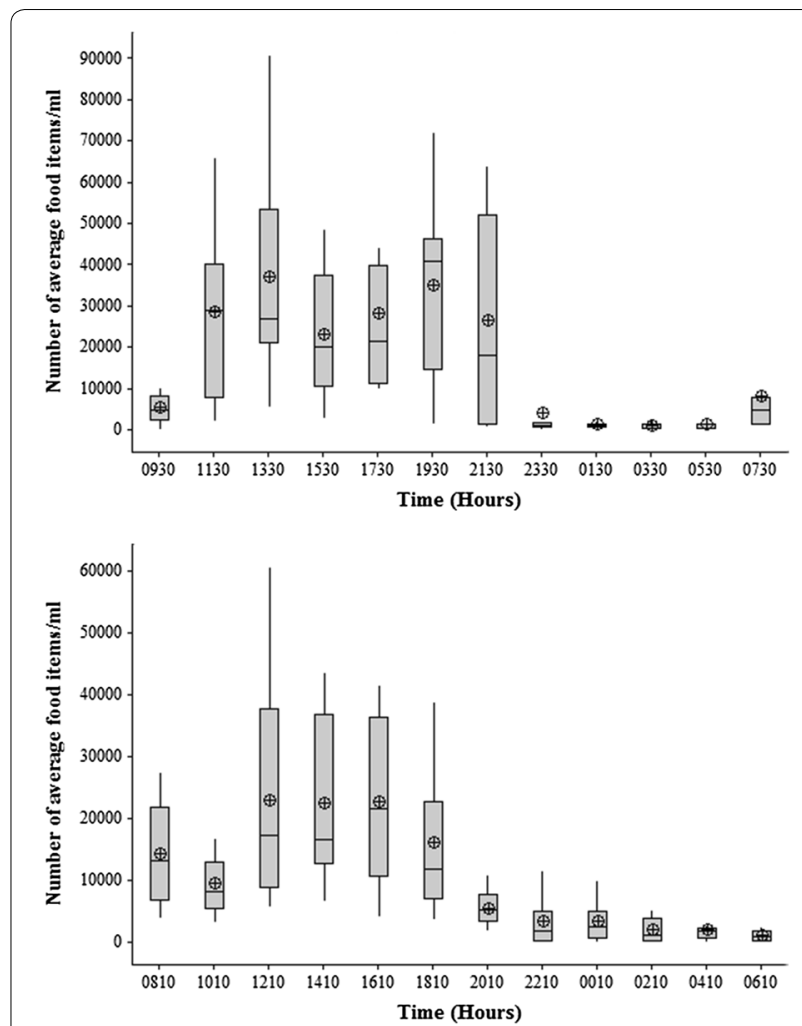

Fig. 6 Fluctuations in number of mean food items with time in the gut contents of $P$. reticulata in $\mathbf{a}$ man-made canal and $\mathbf{b}$ stream. The box plot whiskers depict the range and circled crosses depict the mean number of food items

\section{Discussion}

Contrary to the popular belief that $P$. reticulata is a larvivorus fish $[9,23]$, our results revealed them to be either planktivores or detritivores in the two new environments to which they have been introduced. However, throughout this study and irrespective of the environment, $A$. parvus showed a marked preference for insects and insect larvae over other available food items. Similar observations have been reported by others [24-26], suggesting that the idea that $P$. reticulata is a larvivorous fish is now questionable.

The reasons for diet differences could lie in the relationships between life history and diet. Several authors have confirmed that there is a strong association between the life history and diet of $P$. reticulata [26-28]. Zandonà et al. [26] further revealed that $P$. reticulata found in 


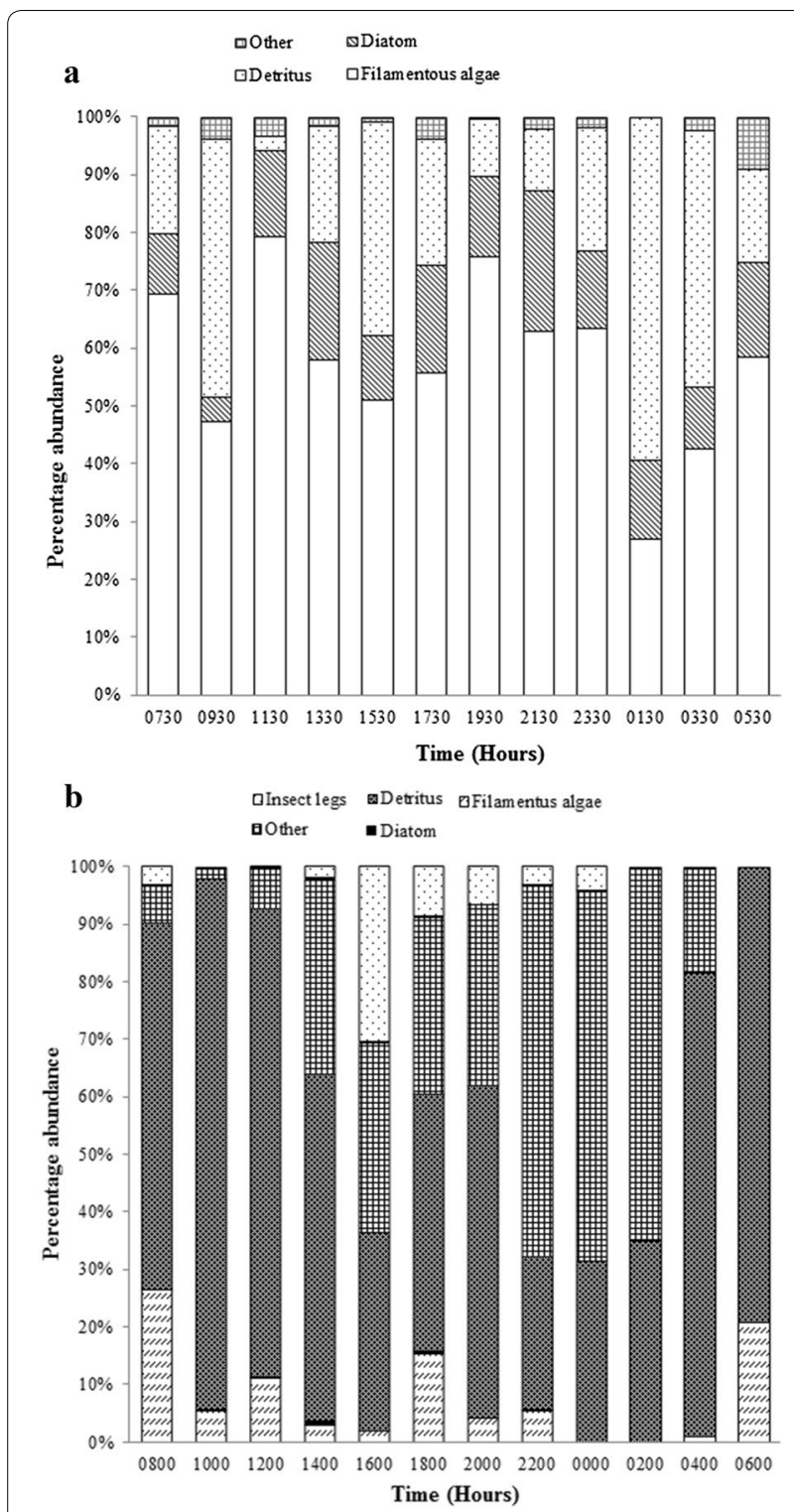

Fig. 7 Diurnal variation of the abundance of different food items in the gut contents of $P$. reticulata sampled from a man-made canal and b natural stream

habitats with high predatory pressure feed primarily on invertebrates whilst under low predatory pressure; they fed primarily on detritus and algae. Additionally, under high predatory pressure, invertebrates with higher nutritional value were selected and consumed, but no such selection was observed under low predatory pressure, where consumption was decided by availability.

Introducing alien fish species can have many negative impacts on the native species $[29,30]$. For instance,
Litoria aurea [31], Litoria dentate [32], Megalagrion spp [33], Edelia vittata [34], Bostockia porosa [34], Galaxias occidentalis [34], Rana muscosa [35], Limnodynastes ornatus [36] and Linderiella occidentalis [37] are some of the native aquatic species that have been affected by introductions of exotic fish species in different parts of the world.

The two species introduced for mosquito control in Sri Lanka, Gambusia affinis, in 1940s and Poecilia reticulata in 1930s from Central America [17] are known invasives [7, 8]. According to current literature, G. affinis has already spread up to Northwestern [38] and Western [39] parts of the country. P. reticulata is also recorded to have spread up to northwestern [38], western [39] and southern [40] provinces. For the current study, the species was collected from Salgala in Sabaragamuwa province, the foot hills of central mountain massif.

It is, therefore, suggested that future plans for any type of biological control using fish should give priority to native species where possible. Use of native fish species rather than exotics has been encouraged [41, 42] and a number of attempts have been made to use them $[13,14$, $43,44]$. This strategy can be justified by the diet composition results for $P$. reticulata in the current study. Further, $P$. reticulata shown a detritivorous consumption in the wild in certain habitats. So, although experimentally this species is capable of consuming insect larvae [45], its use as a biological control can be more harmful than beneficial.

Knowledge of the predatory pressure of a given habitat can be beneficial when introducing $P$. reticulata as larvivorous fish in a particular body of water. By comparing the current findings with those of Zandonà et al. [26], it could be proposed that the natural stream had more predatory pressure than the man-made canal. The current study did not find any aquatic environment where both the species were present naturally, hence the outcomes from this study do not allow comparison of their diet choices when they are co-existing.

\section{Conclusion}

The use of natives over exotics as biological control agents is gaining popularity and this is partly due to issues to do with the invasiveness of exotics. As A. parvus fed during the day as well as during the night, there could be more opportunity for consumption of insect larvae, as well as egg-laying adults, since they are surface feeders. As $P$. reticulata is already considered to be an invasive species, $A$. parvus should be studied further to assess its efficacy as a controlling agent for insects, especially 

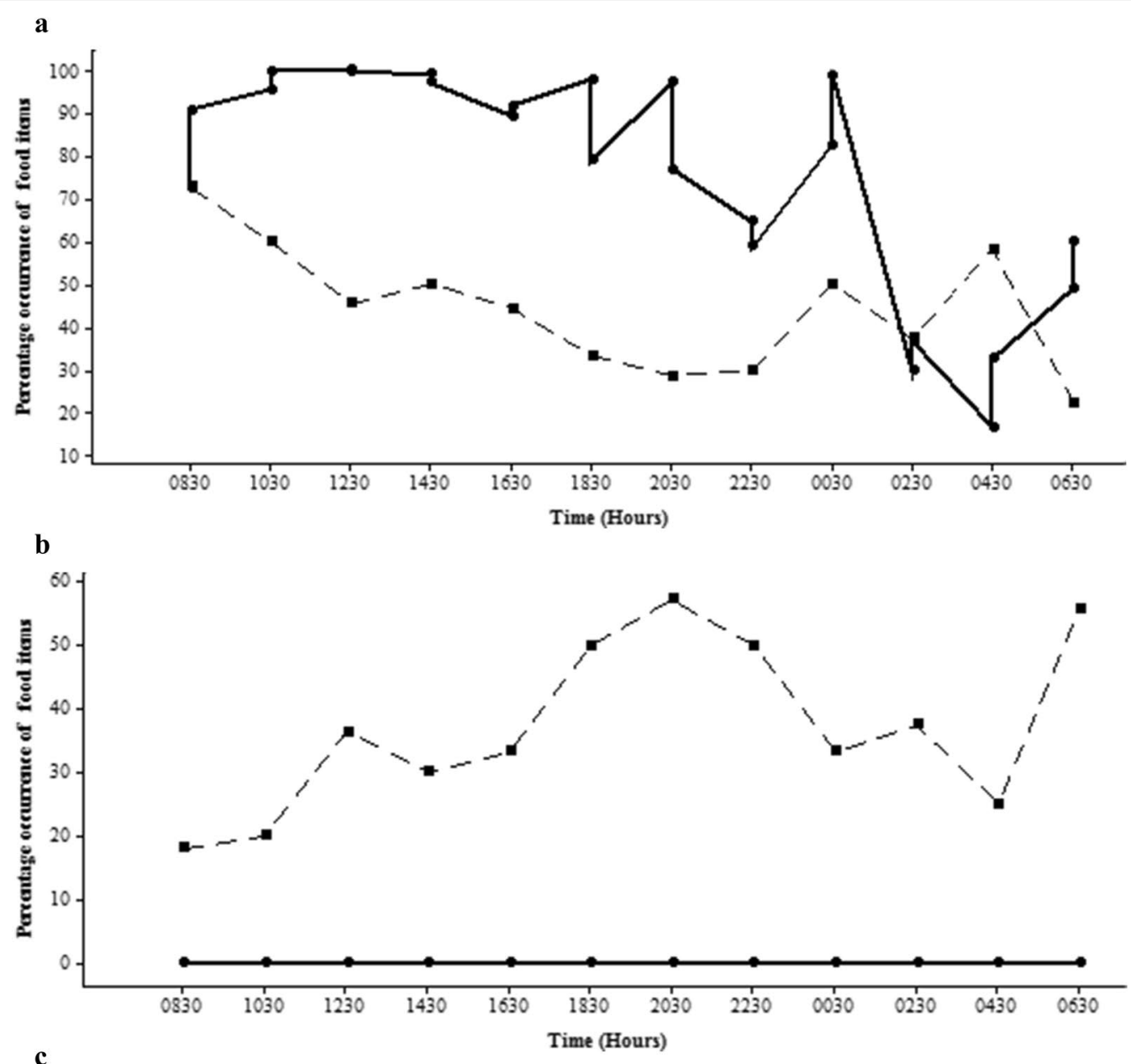

c

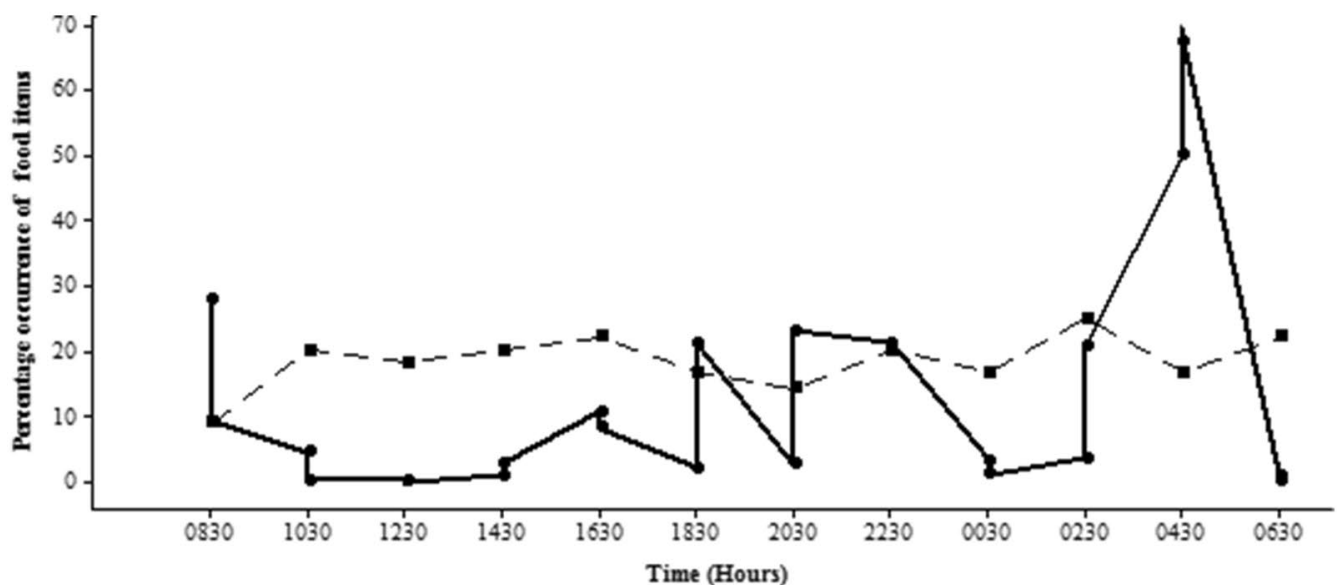

Fig. 8 Diurnal variation of the percentage occurrence of $\mathbf{a}$ zooplankton and insect parts; $\mathbf{b}$ phytoplankton; $\mathbf{c}$ other types of food items in gut contents of A. parvus in the clay quarry pit at different time intervals (Gut-dipicted with circle and solid line; Environment-dipicted with square and hatched line) 

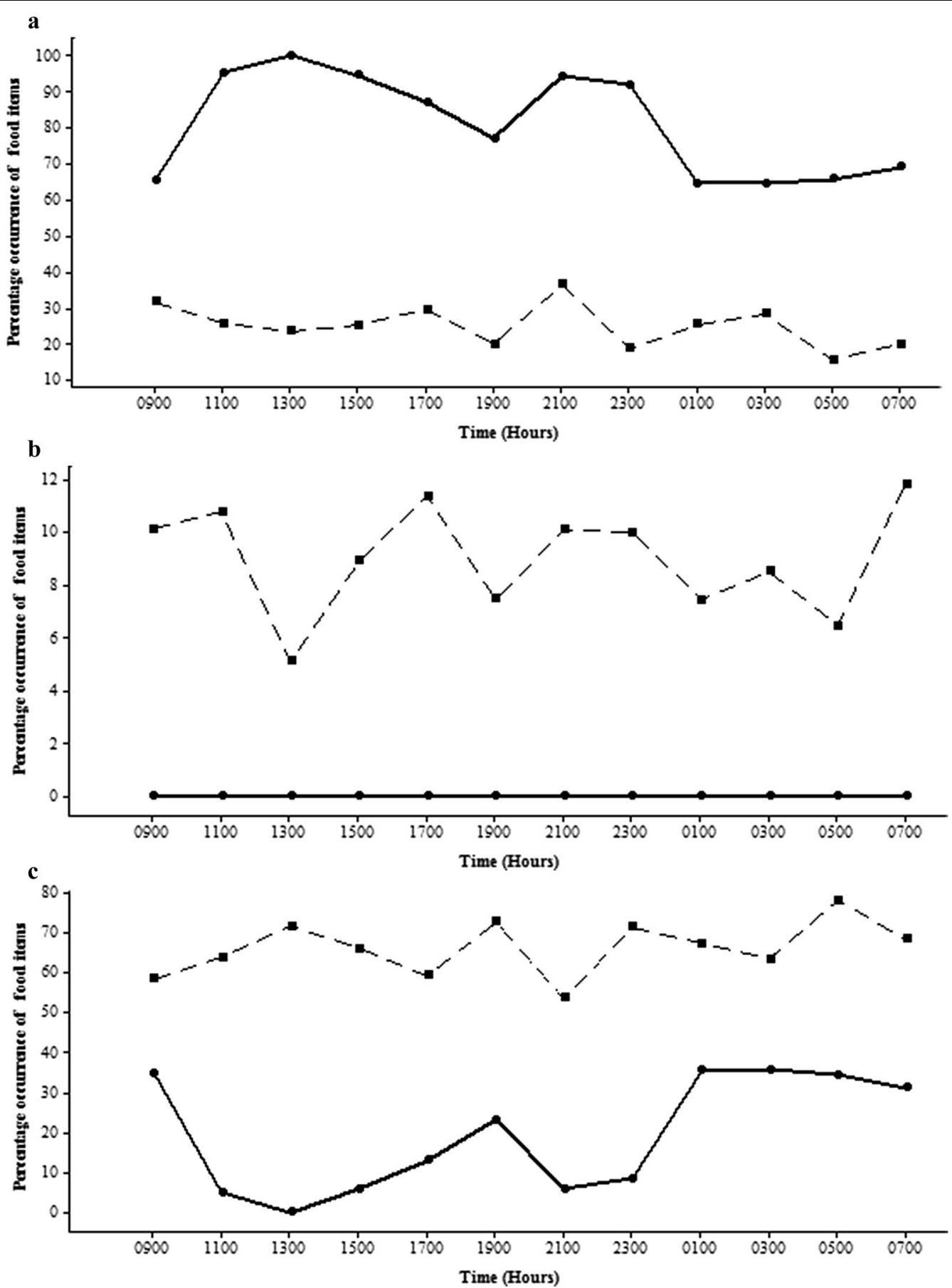

Fig. 9 Diurnal variation of the percentage occurrence of $\mathbf{a}$ zooplankton and insect parts; $\mathbf{b}$ phytoplankton; $\mathbf{c}$ other types of food items in gut contents of A. parvus in the reservoir at different time intervals (Gut-dipicted with circle and solid line; Environment-dipicted with square and hatched line) 

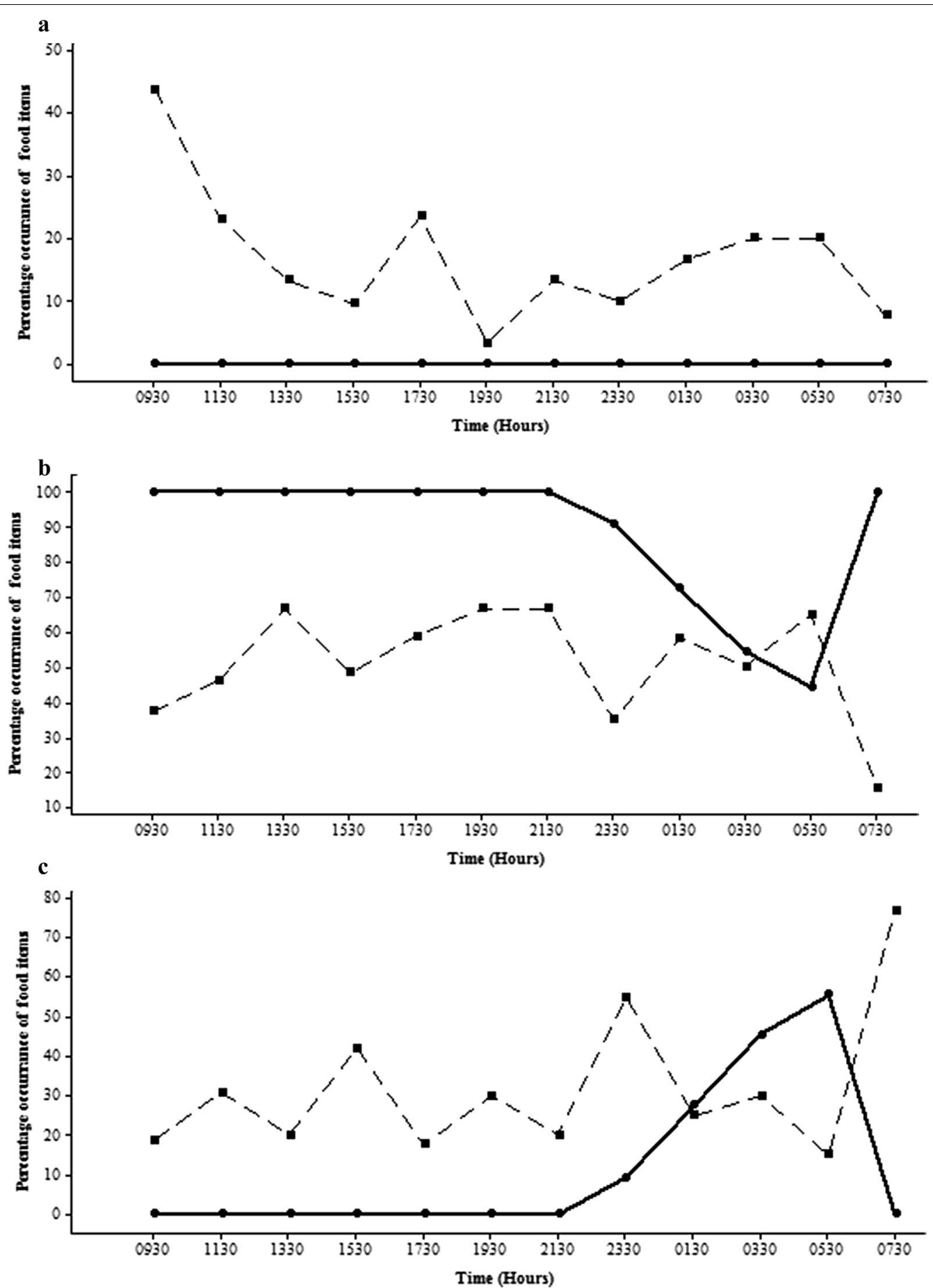

Fig. 10 Diurnal variation of the percentage occurrence of $\mathbf{a}$ zooplankton and insect parts; $\mathbf{b}$ phytoplankton; $\mathbf{c}$ other types of food items in gut contents of $P$.reticulata in the man - made canal at different time intervals (Gut-dipicted with circle and solid line; Environment-dipicted with square and hatched line) 

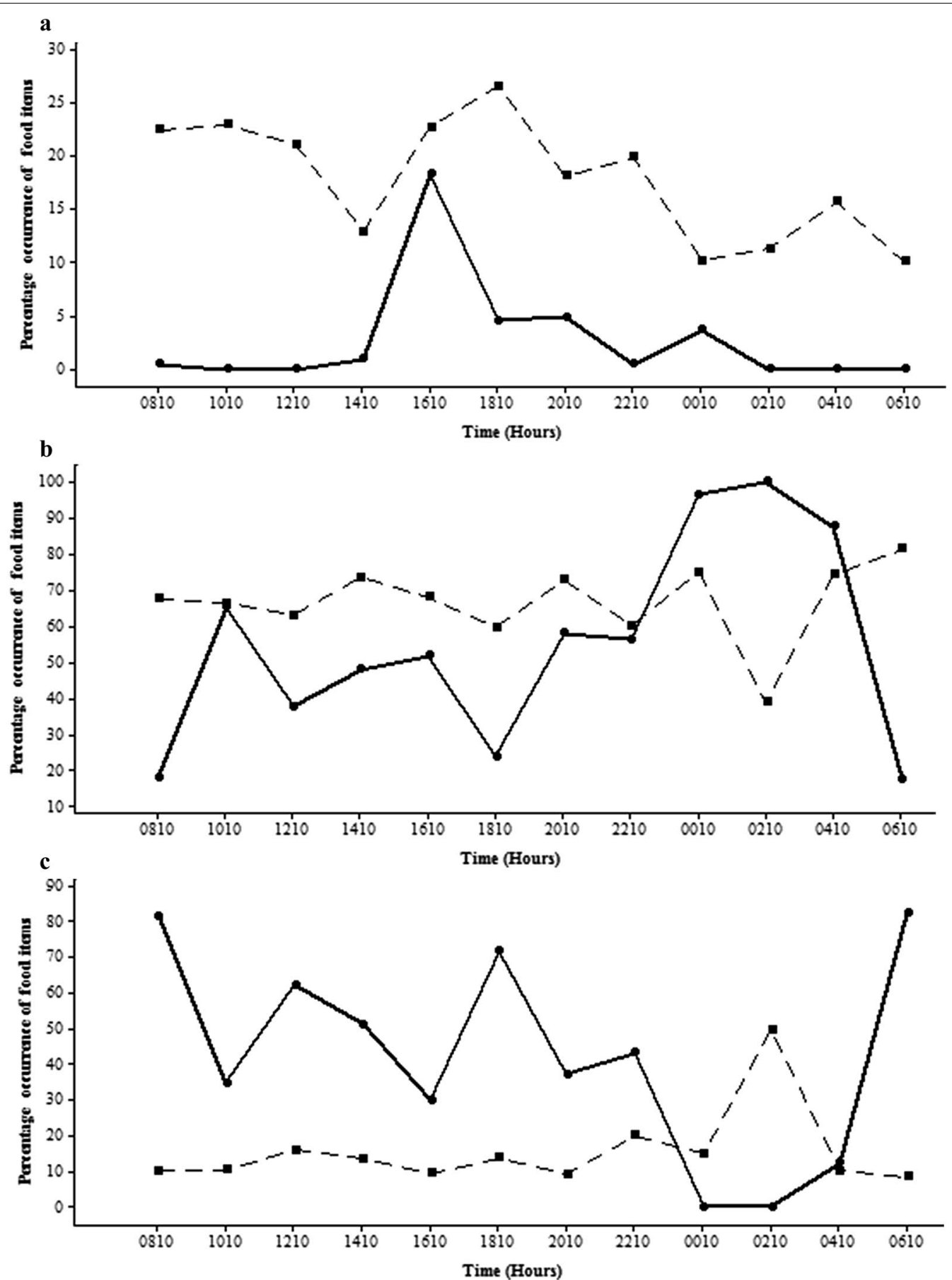

Fig. 11 Diurnal variation of the percentage occurrence of $\mathbf{a}$ zooplankton and insect parts; $\mathbf{b}$ phytoplankton; $\mathbf{c}$ other types of food items in gut contents of $P$. reticulata in the natural stream at different time intervals (Gut-dipicted with circle and solid line; Environment-dipicted with square and hatched line) 
Table 1 Results of the Electivity Index of $A$. parvus inhabiting reservoir and clay quarry pit and $P$. reticulata in man-made canal and stream

\begin{tabular}{lllll}
\hline Species & Habitat & $\begin{array}{l}\text { Zooplankton } \\
\text { and insect } \\
\text { parts }\end{array}$ & Phytoplankton & Other \\
\hline A. parvus & Clay quarry pit & $0.238^{* *}$ & -1.000 & -0.411 \\
& Reservoir & $0.524^{* *}$ & -1.000 & -0.588 \\
P. reticulata & Man-made & -1.000 & $0.264^{* *}$ & -0.654 \\
& canal & & & -0.147 \\
& Natural stream & -0.804 & $0.299^{* *}$ & \\
\hline
\end{tabular}

** Indicates the selection of food item

mosquitoes. However translocation of natives such as A. parvus should be done with care as there are distinct species assemblages even between different water sheds of a given country. A. parvus is a selective feeder and, compared to $P$. reticulata, showed a preference for an insectivorous diet in the habitats studied.

\section{Additional file}

Additional file 1. Plate S1. Food items detected in the sampled clay quarry pit and reservoir a: Filamentous algae $(\times 10)$; b: Detritus $(x 4)$; $c$ : Plant part $(x 4)$; d: Copepod $(x 4)$; e: Insect leg $(x 4)$. Plate S2. Food items identified in the gut of $A$. parvus inhabiting the sampled clay quarry pit and reservoir -a: Coleopteran larvae $(x 4)$; b: Adult Coleopteran $(x 4)$; c: Part of a Coleopteran $(x 4)$; d:e:f: Hymenopterans $(x 4)$; g:h:Insect larval stages $(x)$; i:Copepod. Plate $\mathbf{S} \mathbf{3}$. Food items detected in the sampled natural stream and man-made canal-a: Filamentous algae $(\times 10)$; b: Detritus $(x 4)$; c: Eggs $(x 10)$. Plate S4. Food items identified in the gut of P. reticulata inhabiting the sampled man-made canal-Microscopic field consisted of filamentous algae and diatoms $(\times 4)$.

\section{Authors' contributions}

SJ designed the study protocol and supervised field and laboratory tests throughout the study period. SJ, HKW, AWF, MY and JH carried out the fieldwork. HKW, JH, MY, and GNLG made important suggestions for the experiment throughout the study period and contributed in analysis and interpretation of data. AWF drafted the manuscript and SJ, GNLG, HKW and MY corrected it. All authors read and approved the final manuscript.

\section{Author details}

${ }^{1}$ Department of Aquaculture and Fisheries, Wayamba University of Sri Lanka, Makandura, Gonawila, Sri Lanka. ${ }^{2}$ World Health Organization, Global Malaria Programme, Geneva, Switzerland. ${ }^{3}$ Department of Zoology and Environment Management, University of Kelaniya, Kelaniya, Sri Lanka. ${ }^{4}$ Anti Malaria Campaign, Colombo 05, Sri Lanka.

\section{Acknowledgements}

Wayamba University of Sri Lanka is acknowledged for providing facilities to carry out this research at the Department of Aquaculture and Fisheries. Dr. Angela Sibbald is acknowledged for her comments to improve the manuscript.

\section{Competing interests}

The authors declare that they have no competing interests.

\section{Availability of data and materials}

The datasets used and/or analysed during the current study available from the corresponding author on reasonable request (Additional file 1).

\section{Consent to participate \\ Not applicable.}

\section{Consent to publish}

Not applicable.

\section{Ethics approval and consent to participate}

Ethics approval for this study with regard to collection of fish and subsequent dissection was obtained from the Faculty of Graduate Studies of University of Kelaniya, Sri Lanka at the time of proposal presentation for the overall study. The first author Ms. Fernando completed her M Phil and this manuscript is a part of the study. The approval was obtained in 16.11.2012 (Ref: FGS/07). A. parvus was collected from the wild with the approval of Department of Wildlife Conservation, Sri Lanka (WL/3/2/58/14).

\section{Funding}

Financial support was received as a part of a research project funded by the Global Fund to Fight AIDs, Tuberculosis and Malaria (GFATM). The funding agency approved the research, all field expenses as well as dissemination of outcomes as publications.

\section{Publisher's Note}

Springer Nature remains neutral with regard to jurisdictional claims in published maps and institutional affiliations.

Received: 27 September 2017 Accepted: 31 July 2018

Published online: 14 August 2018

References

1. Ghosh SK, Tiwari SN, Sathyanarayan TS, Sampath TRR, Sharma VP, Nanda $\mathrm{N}$, et al. Larvivorous fish in wells target the malaria vector sibling species of the Anopheles culicifacies complex in villages in Karnataka, India. Trans R Soc Trop Med Hyg. 2005;99:101-5.

2. Frenkel V, Goren M. Factors affecting growth of killifish, Aphanius dispar, a potential biological control of mosquitoes. Aquaculture. 2000;184:255-65.

3. Chandra G, Bhattacharjee I, Chatterjee SN, Ghosh A. Mosquito control by larvivorous fish. Indian J Med Res. 2008;127:13-27.

4. Simberloff D, Stiling P. Risk of species introduced for biological control. Biol Conserv. 1996;78:185-92.

5. Kumar R, Hwang JS. Larvicidal efficiency of aquatic predators: a perspective for mosquito biocontrol. Zool Stud. 2006:45:447-66.

6. Lowe S, Browne M, Boudjelas S, De Poorter M. 100 of the world's worst invasive alien species: a selection from the global invasive species database. Auckland: The Invasive Species Specialist Group (ISSG) a specialist group of the Species Survival Commission (SSC) of the World Conservation Union (IUCN); 2000.

7. Elton CS. The ecology of invasions by animals and plants. Chicago: University of Chicago Press; 2000.

8. Morgan DL, Gill HS, Maddern MG, Beatty SJ. Distribution and impacts of introduced freshwater fishes in Western Australia. N Z J Mar Freshw Res. 2004;38:511-23.

9. Castleberry DT, Cech JJ Jr. Mosquito control in wastewater: a controlled and quantitative comparison of pupfish (Cyprinodon nevadensis amargosae), mosquitofish (Gambusia affinis) and guppies (Poecilia reticulata) in Sago pondweed marshes. J Am Mosq Control Assoc. 1990;6:223-8.

10. Ghosh A, Chandra G. Functional responses of Laccotrephes griseus (Hemiptera: Nepidae) against Culex quinquefasciatus (Diptera: Culicidae) in laboratory bioassay. J Vector Borne Dis. 2011;48:72-7.

11. Rozendaal JA. Vector control: methods for use by individuals and communities. Albany: World Health Organization; 1997.

12. Fletcher M, Teklehaimanot A, Yemane G, Kassahun A, Kidane G, Beyene Y. Prospects for the use of larvivorous fish for malaria control in 
Ethiopia: search for indigenous species and evaluation of their feeding capacity for mosquito larvae. J Trop Med Hyg. 1993;96:12-21.

13. Russell BM, Wang J, Williams Y, Hearnden MN, Kay BH. Laboratory evaluation of two native fishes from tropical North Queensland as biological control agents of subterranean Aedes aegypti. J Am Mosq Control Assoc. 2001;17:124-6.

14. Tranchida MC, Pelizza SA, Bisaro V, Beltrán C, García JJ, Micieli MV. Use of the neotropical fish Cnesterodon decemmaculatus for long-term control of Culex pipiens L. in Argentina. Biol Control. 2010:53:183-7.

15. Wickramasinghe MB, Costa HH. Mosquito control with larvivorous fish. Parasitol Today. 1986;2:228-30.

16. Kumar A, Sharma VP, Sumodan PK, Thavaselvam D. Field trials of biolarvicide Bacillus thuringiensis var. israelensis strain 164 and the larvivorous fish Aplocheilus blocki against Anopheles stephensi for malaria control in Goa, India. J Am Mosq Control Assoc. 1998;14:457-62.

17. De Silva T, Hapuarachchi M, Jayawardena N. Sri Lankan freshwater fishes. Galle: Nations Trust Bank; 2015.

18. Fernando GKAW, Jayakody S, Wijenayake WMHK, Gapappaththy GNL, Yatawara DMDWMMK, Harischandra RDJ, et al. Diurnal variation in the feeding patterns and food preferences of Dwarf panchax (Aplocheilus parvus). Sri Lanka J Aquat Sci. 2015;20:19-29.

19. Goswami SC. Zooplankton methodology, collection \& identification-a field manual. Dona Paula: National Institute of Oceanography; 2004

20. Suthers IM, Rissik D. Plankton: a guide to their ecology and monitoring for water quality. Clayton: CSIRO PUBLISHING; 2009.

21. Hyslop EJ. Stomach contents analysis-a review of methods and their application. J Fish Biol. 1980;17:411-29.

22. Fernando $\mathrm{CH}$. The freshwater fauna and fisheries of Sri Lanka. Colombo: Natural Resources, Energy and Science Authority of Sri Lanka; 1990.

23. Kusumawathie PHD, Wickremasinghe AR, Karunaweera ND, Wijeyaratne MJS. Larvivorous potential of fish species found in river bed pools below the major dams in Sri Lanka. J Med Entomol. 2006;43:79-82.

24. Dussault GV, Kramer DL. Food and feeding behavior of the guppy, Poecilia reticulata (Pisces: Poeciliidae). Can J Zool. 1981;59:684-701.

25. Zandona E. The trophic ecology of guppies (Poecilia reticulata) from the streams of Trinidad. Philadelphia: Drexel University; 2010.

26. Zandona E, Auer SK, Kilham SS, Howard JL, López-Sepulcre A, O'Connor MP, Bassar RD, Osorio A, Pringle CM, Reznick DN. Diet quality and prey selectivity correlate with life histories and predation regime in Trinidadian guppies. Funct Ecol. 2011;25:964-73.

27. Reznick D, Endler JA. The impact of predation on life history evolution in Trinidadian guppies (Poecilia reticulata). Evolution (N. Y). 1982:36:160-77.

28. Reznick DN. Life-history evolution in guppies: 2. Repeatability of field observations and the effects of season on life histories. Evolution (N. Y). 1989:43:1285-97.

29. Crowl TA, Townsend CR, Mcintosh AR. The impact of introduced brown and rainbow trout on native fish: the case of Australasia. Rev Fish Biol Fish. 1992;2:217-41.

30. Latini AO, Petrere M. Reduction of a native fish fauna by alien species: an example from Brazilian freshwater tropical lakes. Fish Manag Ecol. 2004;11:71-9.
31. Hamer A, Lane S, Mahony M. The role of introduced mosquitofish (Gambusia holbrooki) in excluding the native green and golden bell frog (Litoria aurea) from original habitats in south-eastern Australia. Oecologia. 2002;132:445-52.

32. Morgan LA, Buttemer WA. Predation by the non-native fish Gambusia holbrooki on small Litoria aurea and L. dentata tadpoles. Aust Zool. 1996:30:143-9.

33. Englund RE. The impacts of introduced poeciliid fish and Odonata on the endemic Megalagrion (Odonata) damselflies of Oahu Island, Hawaii. J Insect Conserv. 1999;3:225-43.

34. Gill HS, Hambleton SJ, Morgan DL. Is the Mosquitofish, Gambusia holbrooki (Poeciliidae), a major threat to the native freshwater fishes of south-western Australia?.In: 5th Indo-Pacific Fish Conference, 3-8 November 1997, Noumea, New Caledonia 1999;79-87.

35. Knapp RA, Matthews KR. Non-native fish introductions and the decline of the mountain yellow legged frog from within protected areas. Conserv Biol. 2000; 14:428-38.

36. Komak S, Crossland MR. An assessment of the introduced mosquitofish (Gambusia affinis holbrooki) as a predator of eggs, hatchlings and tadpoles of native and non-native anurans. Wildlife Res. 2000;27:185-9.

37. Leyse KE, Lawler SP, Strange T. Effects of an alien fish, Gambusia affinis, on an endemic California fairy shrimp, Linderiella occidentalis: implications for conservation of diversity in fishless waters. Biol Conserv. 2004;1 18:57-65.

38. Weerasinghe SM. North Western Province Biodiversity profile and Conservation Action plan. Colombo: A publication of Biodiversity Secretariat, Ministry of Environment and Natural Resources; 2008.

39. Bambaradeniya C. North Western Province Biodiversity profile and Conservation Action plan. Colombo: A publication of Biodiversity Secretariat, Ministry of Environment and Natural Resources; 2008.

40. Gunawardena A. North Western Province Biodiversity profile and Conservation Action plan. Colombo: A publication of Biodiversity Secretariat, Ministry of Environment and Natural Resources; 2008.

41. Howarth FG. Environmental impacts of classical biology control. Annu Rev Entomol. 1991;36:485-509.

42. Marti GA, Azpelicueta MDLM, Tranchida MC, Pelizza SA, García JJ. Predation efficiency of indigenous larvivorous fish species on Culex pipiens L. larvae (Diptera: Culicidae) in drainage ditches in Argentina. J Vector Ecol. 2006:31:102-6

43. Nelson SM, Keenan LC. Use of an indigenous fish species, Fundulus zebrinus, in a mosquito abatement program: a field comparison with the mosquitofish, Gambusia affinis. J Am Mosq Control Assoc. 1992;8:301-4.

44. Willems KJ, Webb CE, Russell RC. A comparison of mosquito predation by the fish Pseudomugil signifier Kner and Gambusia holbrooki (Girard) in laboratory trials. J Vector Ecol. 2005;30:87-90.

45. Karlekar SR, Andrew RJ. Assessment of mosquito Culex quinquefasciatus larvivorous prospective of the fish Poecilia reticulata and Gambusia affinis. Biol Forum Int J. 2016;8:326-9.

Ready to submit your research? Choose BMC and benefit from

- fast, convenient online submission

- thorough peer review by experienced researchers in your field

- rapid publication on acceptance

- support for research data, including large and complex data types

- gold Open Access which fosters wider collaboration and increased citations

- maximum visibility for your research: over 100M website views per year

At BMC, research is always in progress.

Learn more biomedcentral.com/submissions 